\title{
THE EFFECT OF SODIUM CHLORIDE DEPLETION ON BLOOD PRESSURE AND TETRAETHYLAMMONIUM CHLORIDE RESPONSE IN HYPERTENSION ${ }^{1}$
}

\author{
By WILLIAM W. STEAD,2 MORTON F. REISER, SAMUEL RAPOPORT, \\ AND EUGENE B. FERRIS
}

\author{
(From the Department of Internal Medicine, College of Medicine, University of Cincinnati, the \\ Cincinnati General Hospital, and The Research Foundation of the \\ Children's Hospital, Cincinnati)
}

(Received for publication July 10, 1948)

A number of investigators have presented evidence to show that a diet poor in sodium may lower the blood pressure of hypertensive patients (1-7). Others have concluded that the blood pressure changes observed in association with sodium restriction are fortuitous (8-13). Recently Perera (6) has shown a small but significant decrease in the early morning blood pressure of a group of hospitalized hypertensive patients in response to a low sodium intake. In his patients the fall in blood pressure was not accompanied by a change in plasma volume, cardiac output, or serum sodium concentration.

In view of the conflicting evidence, it seemed worthwhile to learn first whether more rigid salt deprivation could produce more definite changes in the daily random blood pressure than those previously reported; and second, to define, if possible, the physiologic mechanism concerned in the changes associated with drastic shifts in the sodium balance.

It was thought that information on the latter problem could be obtained by observing the effects of changes in salt balance not only on the random blood pressure, but also on the response of the blood pressure to the tetraethylammonium ion. Since it has been shown that this drug blocks the transmission of impulses by the autonomic ganglia $(14,15)$, it should be possible to evaluate the relative rôles of neurogenic and humoral tone in the maintenance of the blood pressure (16-20).

\section{MATERIAL AND METHODS}

Twelve patients with severe and persistent hypertension were studied to determine the effects of severe sodium

1 Read in abstract form at the meeting of the American Society for Clinical Investigation, May 3, 1948, Atlantic City, N. J.

2 Present address: Department of Medicine, Veterans Administration Hospital, Minneapolis, Minn. deprivation and then the effects of added sodium upon both daily blood pressure and response to the tetraethylammonion ion. Table I shows the nature of the clinical material. All the patients but one were studied on the medical wards of the Cincinnati General Hospital. No attempt was made to select the patients by type of hypertension. The only essential criterion was a willingness to cooperate in rigid dietary restrictions and to submit to prolonged study in the hospital.

Tetraethylammonium chloride ${ }^{3}$ (TEAC) was used intravenously in a standard dose of $400 \mathrm{mgm}$. (4 cc. of solution) and three separate blood pressure values determined: (1) The pre-test blood pressure to which we shall refer as the "random pressure" since we had no fixed hour for testing the patients. (2) The blood pressure during the maximum effect of the TEAC-the "TEAC floor." (3) The fall in blood pressure produced by the drug-the "TEAC response." Because of the rapid and short action of TEAC, determination of random pressure and TEAC floor can be made at daily intervals without affecting the random blood pressure level or the TEAC floor from day to day (22).

The standard procedure for a single evaluation was to take blood pressure readings at minute intervals, with the patient at rest in the supine position for five minutes or longer, until the readings remained consistent for three consecutive minutes. TEAC was then injected rapidly into the antecubital vein of the opposite arm and blood pressure readings determined at 30 to 60 second intervals for six to ten minutes or until the pressure had begun to return toward the starting level. The random blood pressure was taken as the arithmetic mean of three consecutive readings (variation not more than $5 \mathrm{~mm} . \mathrm{Hg}$ systolic and diastolic) just prior to the injection of the drug. The TEAC floor was recorded as the arithmetic mean of the three lowest pressures reached after the injection of TEAC, taking readings every 30 seconds. The TEAC response was recorded as the difference between the random blood pressure and the TEAC floor. All determinations were done by the same observer. No attempt was made to test the patients in the "basal" state, since we were interested in random pressure levels.

The above studies were carried out during alternate periods of severe salt deprivation and of added salt until

3 Etamon Chloride, furnished by Parke, Davis \& Co., Detroit, Michigan, through the courtesy of Dr. E. C. Vonder Heide. 
TABLE I

Summary of the clinical material

\begin{tabular}{|c|c|c|c|c|c|c|c|}
\hline \multirow{2}{*}{$\begin{array}{l}\text { Name } \\
\text { Number }\end{array}$} & \multirow{2}{*}{$\begin{array}{l}\text { Age } \\
\text { Color } \\
\text { Sex }\end{array}$} & \multirow{2}{*}{$\begin{array}{l}\text { Clinical } \\
\text { diagnosis }\end{array}$} & \multirow{2}{*}{ Cardiac status } & \multicolumn{2}{|c|}{ Renal status } & \multirow{2}{*}{$\begin{array}{c}\text { Central } \\
\text { nervous system }\end{array}$} & \multirow{2}{*}{$\underset{\text { (grade*) }}{\text { Fundi }}$} \\
\hline & & & & $\begin{array}{l}\text { PSP } \\
\text { test }\end{array}$ & $\underset{(m g m . \%)}{\text { BUN }}$ & & \\
\hline \multicolumn{8}{|c|}{ Group I } \\
\hline$\underset{153456}{\text { M. S. }}$ & $\begin{array}{c}56 \\
\text { Col. } \\
\text { Female }\end{array}$ & $\begin{array}{l}\text { Benign } \\
\text { essent. } \\
\text { hypertens. }\end{array}$ & $\begin{array}{l}\text { Normal function } \\
\text { Size: upper normal } \\
\text { L. axis deviation }\end{array}$ & $\begin{array}{ll}15^{\prime} & 20 \% \\
60^{\prime} & 65 \%\end{array}$ & 15 & Normal & II \\
\hline $\begin{array}{l}\text { E. E. } \\
232262\end{array}$ & $\begin{array}{c}36 \\
\text { White } \\
\text { Female }\end{array}$ & $\begin{array}{l}\text { Benign } \\
\text { essent. } \\
\text { hypertens. }\end{array}$ & $\begin{array}{l}\text { Recent CHF } \dagger \\
\text { L. vent. enlarged } \\
\text { Myocard. damage (EKG) }\end{array}$ & $\begin{array}{lr}15^{\prime} & 5 \% \\
60^{\prime} & 25 \%\end{array}$ & $22-35$ & $\begin{array}{l}\text { Acute hyper- } \\
\text { tensive enceph- } \\
\text { alopathy }\end{array}$ & II \\
\hline$\underset{231718}{\text { M. H. }}$ & $\begin{array}{c}42 \\
\text { Col. } \\
\text { Female }\end{array}$ & $\begin{array}{l}\text { Benign } \\
\text { essent. } \\
\text { hypertens. }\end{array}$ & $\begin{array}{l}\text { Recent CHF } \\
\text { "Slightly enlarged" } \\
\text { L. bund. br. block }\end{array}$ & $\begin{array}{rr}15^{\prime} & 5 \% \\
60^{\prime} & 60 \%\end{array}$ & 14 & Normal & I \\
\hline G. L. & $\begin{array}{c}37 \\
\text { Col. } \\
\text { Female }\end{array}$ & $\begin{array}{l}\text { Benign } \\
\text { essent. } \\
\text { hypertens. }\end{array}$ & $\begin{array}{l}\text { Recent CHF } \\
\text { Moderately enlarged } \\
\text { "L. vent. strain" (EKG) }\end{array}$ & $\begin{array}{ll}15^{\prime} & 10 \% \\
60^{\prime} & 60 \%\end{array}$ & 14 & $\begin{array}{l}\text { Previous small } \\
\text { thromboses }\end{array}$ & II \\
\hline $\begin{array}{l}\text { B. C. } \\
4900\end{array}$ & $\begin{array}{c}58 \\
\text { Col. } \\
\text { Female }\end{array}$ & $\begin{array}{l}\text { Benign } \\
\text { essent. } \\
\text { hypertens. }\end{array}$ & $\begin{array}{l}\text { Recent CHF } \\
\text { Markedly enlarged } \\
\text { "L. vent. strain" (EKG) }\end{array}$ & $\begin{array}{ll}15^{\prime} & 20 \% \\
60^{\prime} & 58 \%\end{array}$ & 14 & Normal & III \\
\hline
\end{tabular}

Group II

\begin{tabular}{|c|c|c|c|c|c|c|c|}
\hline$\underset{4788}{\text { L. M. }}$ & $\begin{array}{l}34 \\
\text { Col. } \\
\text { Female }\end{array}$ & $\begin{array}{l}\text { Benign } \\
\text { essent. } \\
\text { hypertens. }\end{array}$ & $\begin{array}{l}\text { Recent CHF } \\
\text { Markedly enlarged } \\
\text { Myocard. damage }\end{array}$ & $\begin{array}{ll}15^{\prime} & 10 \% \\
60^{\prime} & 40 \%\end{array}$ & $23-30$ & $\begin{array}{l}\text { Chronic hyper- } \\
\text { tensive enceph- } \\
\text { alopathy }\end{array}$ & II \\
\hline $\begin{array}{l}\text { I. H. H. } \\
231469\end{array}$ & $\begin{array}{c}36 \\
\text { Col. } \\
\text { Female }\end{array}$ & $\begin{array}{l}\text { Malignant } \\
\text { hypertens. }\end{array}$ & $\begin{array}{l}\text { Function normal } \\
\text { Markedly enlarged } \\
\text { "L. vent. strain" (EKG) }\end{array}$ & $\begin{array}{ll}15^{\prime} & 3 \% \\
60^{\prime} & 5 \%\end{array}$ & $48-180$ & $\begin{array}{l}\text { Acute hyper- } \\
\text { tensive enceph- } \\
\text { alopathy }\end{array}$ & IV \\
\hline$\underset{11082}{F . R .}$ & $\begin{array}{l}44 \\
\text { White } \\
\text { Female }\end{array}$ & $\begin{array}{l}\text { Malignant } \\
\text { hypertens. }\end{array}$ & $\begin{array}{l}\text { Function normal } \\
\text { L. vent. hypertrophy } \\
\text { Myocard. damage }\end{array}$ & $\begin{array}{lr}15^{\prime} & 2 \% \\
60^{\prime} & 10 \%\end{array}$ & $18-180$ & $\begin{array}{l}\text { Chronic hyper- } \\
\text { tensive enceph- } \\
\text { alopa thy }\end{array}$ & IV \\
\hline$\underset{231439}{J}$ & $\begin{array}{l}57 \\
\text { Col. } \\
\text { Male } \\
\end{array}$ & $\begin{array}{l}\text { Malignant } \\
\text { hypertens. }\end{array}$ & $\begin{array}{l}\text { Recent CHF } \\
\text { Markedly enlarged } \\
\text { "L. vent. strain" (EKG) }\end{array}$ & $\begin{array}{ll}15^{\prime} & 0 \% \\
60^{\prime} & 0 \%\end{array}$ & $95-160$ & $\begin{array}{l}\text { Clouded } \\
\text { (uremia) }\end{array}$ & IV \\
\hline F.S. & $\begin{array}{l}42 \\
\text { Col. } \\
\text { Female }\end{array}$ & $\begin{array}{l}\text { Benign } \\
\text { essent. } \\
\text { hypertens. }\end{array}$ & $\begin{array}{l}\text { Recent CHF } \\
\text { Markedly enlarged }\end{array}$ & $\begin{array}{ll}15^{\prime} & 0 \% \\
60^{\prime} & 0 \%\end{array}$ & $110-180$ & $\begin{array}{l}\text { Clouded } \\
\text { (uremia) }\end{array}$ & II \\
\hline $\begin{array}{l}\text { A. B. } \\
232772\end{array}$ & $\begin{array}{c}33 \\
\text { Col. } \\
\text { Female }\end{array}$ & $\begin{array}{l}\text { Malignant } \\
\text { hypertens. }\end{array}$ & $\begin{array}{l}\text { Function normal } \\
\text { Moderately enlarged } \\
\text { "L. vent. strain" (EKG) }\end{array}$ & $\begin{array}{ll}15^{\prime} & 0 \% \\
60^{\prime} & 2 \%\end{array}$ & $105-160$ & $\begin{array}{l}\text { Clouded } \\
\text { (uremia) }\end{array}$ & IV \\
\hline $\begin{array}{l}\text { F. I. } \\
221329\end{array}$ & $\begin{array}{l}41 \\
\text { White } \\
\text { Male }\end{array}$ & $\begin{array}{l}\text { Malignant } \\
\text { hypertens. }\end{array}$ & $\begin{array}{l}\text { Function normal } \\
\text { Moderately enlarged } \\
\text { Normal EKG }\end{array}$ & $\begin{array}{ll}15^{\prime} & 30 \% \\
60^{\prime} & 60 \%\end{array}$ & 15 & $\begin{array}{l}\text { Chronic hyper- } \\
\text { tensive enceph- } \\
\text { alopathy }\end{array}$ & IV \\
\hline
\end{tabular}

* Classification of Gifford (21).

$\dagger$ CHF: Congestive heart failure.

a characteristic and reproducible response was obtained for each patient, or until further study was not feasible. A more detailed description of these periods is as follows:

(1) Control period. Upon admission to the hospital, or as soon thereafter as the complicating condition would permit, several random pressures and TEAC floors were determined while the patient was on a general house diet. There were two exceptions: Patient B. C. was not studied in the initial control period because she had been admitted in congestive failure and placed on an effective desalting regimen from the outset. Two subsequent periods of added salt serve as control for her studies, however. Patient F. I. was studied as an ambulatory clinic patient on a regular diet. 
(2) "Desalted" period. Following the control period each patient was placed on a low sodium diet which was continued for the duration of the study, except for brief interruptions in the early study of patients G. L. and $\mathrm{M}$. H. In all but one of the cases, the diet was calculated to contain 0.2 to $0.25 \mathrm{Gm}$. sodium $(0.5 \mathrm{Gm}$. sodium chloride) per day. The one exception, A. B., had very low renal reserve and was given a diet containing 0.9 $\mathrm{Gm}$. sodium. The diets were carefully supervised by one member of the Dietetics Department of the Cincinnati General Hospital. Adequate protein allowance, in the face of such rigid sodium restriction, was made possible by the use of a low sodium milk. ${ }^{4}$ In order to achieve an even greater degree of sodium depletion, mercuhydrin was administered to eight patients in doses of 2 cc. intramuscularly from one to three times per week during

${ }^{4}$ Lonalac, generously furnished by Meade Johnson \& Company, Evansville, Indiana. the desalting periods. Such a regimen of sodium deprivation was continued for periods of seven to 21 days. The random pressure and TEAC floor were determined two to 19 times while the patient was on this regimen.

(3) "Salted" period. In the six patients whose condition permitted further study, the mercuhydrin was discontinued and $2.4 \mathrm{Gm}$. sodium (in the form of $6 \mathrm{Gm}$. sodium chloride in enteric coated tablets) was given daily without a change in the diet, for a period of seven to 12 days. Although the salt added to the regimen constituted only about half the average daily salt intake of adults, this procedure seemed desirable since several of the patients had a history of recent congestive failure. Because of the importance of psychologic factors in hypertension, care was taken not to reveal to the patients the significance of the change in the regimen.

In six patients it was possible to study the changes produced by several alternations of the sodium balance,

TABLE II

Salted versus desalted state-Group I

Comparison of the means and standard errors of random blood pressure, TEAC floor and TEAC response

\begin{tabular}{|c|c|c|c|c|c|c|c|c|c|c|c|c|}
\hline Patient & State & $\begin{array}{l}\text { Periods } \\
\text { studied }\end{array}$ & $\begin{array}{c}\text { Number } \\
\text { of deter- } \\
\text { minations }\end{array}$ & $\begin{array}{c}\text { Random } \\
\text { blood } \\
\text { pressure }\end{array}$ & $\begin{array}{l}\text { Stand. } \\
\text { error }\end{array}$ & P* & $\begin{array}{l}\text { TEAC } \\
\text { floor }\end{array}$ & $\begin{array}{l}\text { Stand. } \\
\text { error }\end{array}$ & $\mathrm{P}^{*}$ & $\begin{array}{l}\text { TEAC } \\
\text { response }\end{array}$ & $\begin{array}{l}\text { Stand. } \\
\text { error }\end{array}$ & $\mathrm{P}^{*}$ \\
\hline \multirow{4}{*}{ M. S. } & \multirow{2}{*}{ Salt } & \multirow{2}{*}{3} & \multirow{2}{*}{15} & $\underset{212.5}{m m . H g}$ & $\begin{array}{c}m m . \\
\pm 4.7 \\
\pm 4.7\end{array}$ & \multirow[b]{2}{*}{.01} & $\underset{155.4}{\operatorname{mm}_{15} . \mathrm{Hg}}$ & $\begin{array}{c}m m . ~ \\
\pm 4.7 \\
4.7\end{array}$ & \multirow[b]{2}{*}{.001} & ${ }_{57.1}^{m H_{g}}$ & $\begin{array}{c}m m . H g \\
\pm 5.3\end{array}$ & \multirow[b]{2}{*}{.001} \\
\hline & & & & $\overline{116.3}$ & $\overline{ \pm 3.1}$ & & 89.4 & \pm 3.0 & & 26.9 & \pm 2.9 & \\
\hline & \multirow{2}{*}{ Desalt } & \multirow{2}{*}{3} & \multirow{2}{*}{37} & 196.3 & \pm 3.3 & \multirow[t]{2}{*}{.7} & 108.3 & \pm 5.3 & \multirow[t]{2}{*}{.001} & 88.0 & \pm 6.7 & \multirow[t]{2}{*}{.001} \\
\hline & & & & 114.8 & \pm 2.7 & & 67.4 & \pm 3.2 & & 47.4 & \pm 3.6 & \\
\hline \multirow{4}{*}{ E. E. } & \multirow{2}{*}{ Salt } & \multirow{2}{*}{4} & \multirow{2}{*}{20} & 200.0 & \pm 7.5 & \multirow[b]{2}{*}{.001 } & 156.9 & \pm 7.0 & \multirow[b]{2}{*}{.001} & 43.1 & \pm 6.5 & \multirow[b]{2}{*}{.01} \\
\hline & & & & 104.6 & \pm 3.8 & & 84.5 & \pm 3.2 & & 20.1 & \pm 2.6 & \\
\hline & \multirow{2}{*}{ Desalt } & \multirow{2}{*}{3} & \multirow{2}{*}{27} & 174.4 & \pm 4.8 & \multirow[t]{2}{*}{.1} & 106.0 & \pm 5.2 & \multirow[t]{2}{*}{.001} & 68.0 & \pm 5.8 & \multirow[t]{2}{*}{.001 } \\
\hline & & & & 97.4 & \pm 2.2 & & 64.4 & \pm 2.8 & & 33.0 & \pm 3.3 & \\
\hline \multirow{4}{*}{ M. H. } & \multirow{2}{*}{ Salt } & \multirow{2}{*}{2} & \multirow{2}{*}{11} & 175.5 & \pm 3.2 & \multirow[b]{2}{*}{.01} & 135.6 & \pm 4.3 & \multirow[b]{2}{*}{.001} & 39.9 & \pm 5.3 & \\
\hline & & & & 105.9 & \pm 2.0 & & 79.1 & \pm 2.6 & & 26.8 & \pm 3.1 & .001 \\
\hline & & & & 163.8 & \pm 2.9 & .6 & 89.7 & \pm 5.0 & .001 & 74.1 & \pm 6.4 & .01 \\
\hline & Desalt & 2 & 10 & 103.2 & \pm 4.7 & & 58.1 & \pm 4.6 & & 45.1 & \pm 4.5 & \\
\hline & C. & ? & 12 & 232.2 & \pm 4.1 & & 196.7 & \pm 4.6 & & 35.5 & \pm 5.1 & \\
\hline C I & Salt & 2 & 10 & 131.3 & \pm 2.4 & .001 & 123.6 & \pm 2.5 & .001 & 7.6 & \pm 3.2 & .2 \\
\hline G. L. & & & & 198.0 & \pm 4.9 & .3 & 152.4 & \pm 5.2 & .001 & 45.6 & \pm 5.4 & .05 \\
\hline & Desalt & 2 & 16 & 126.4 & \pm 3.7 & & 109.0 & \pm 3.9 & & 17.4 & \pm 4.0 & \\
\hline & Colt & 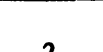 & 17 & 228.0 & \pm 3.2 & & 174.8 & \pm 4.4 & & 43.2 & \pm 5.4 & \\
\hline & Salt & 2 & 10 & 107.5 & \pm 2.4 & .1 & 91.3 & \pm 2.1 & .001 & 16.2 & \pm 1.8 & .001 \\
\hline D. & Drno & 2 & 24 & 220.0 & $c \pm 3.5$ & .3 & 134.3 & \pm 4.3 & .001 & 85.7 & \pm 5.2 & .001 \\
\hline & Hesaic & 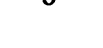 & $0 x$ & 104.3 & \pm 2.0 & & 74.3 & \pm 2.2 & & 30.0 & \pm 2.3 & \\
\hline
\end{tabular}

* Probability that the observed change could have been due to chance alone. Values of $\mathrm{P}$ of 0.05 or less are usually considered significant. 
i.e., several "salted" and "desalted" periods. This afforded an opportunity to observe the consistency of the response of the patients to repeated changes in the regimen.

In nine patients random pressures and TEAC floors were determined at intervals varying from one to three days. They were observed from 14 to 63 days. In the remaining three patients, the blood pressures and TEAC floors were determined less frequently. A total of 268 determinations of the blood pressures and TEAC floors were made in the 12 patients.

Serum sodium levels were determined in seven patients at the height of the salting and desalting regimens without regard for alterations in the random blood pressure and TEAC floor. The uranyl-zinc acetate gravimetric method (23) was used for these determinations. The blood samples were drawn under oil and the serum separated from the cells within two hours.

The weight of the patients was recorded as often as practical. All patients were observed closely for signs and symptoms of salt deprivation and of dehydration.

In three patients the cardiac output determinations were made both in a salted and a desalted period by means of the ballistocardiograph. Repeated tracings were taken during routine determination of the random blood pressure and TEAC floor.

\section{RESULTS}

The results will be considered in two groups divided on the basis of alterability of blood pressure and/or TEAC floor by sodium deprivation.
Group I. Five patients consistently showed a fall in random blood pressure and/or TEAC floor during desalted periods as compared with salted periods. All of these patients had severe benign essential hypertension and only moderately impaired renal function. They were studied a total of 204 times with TEAC, through 13 salted and control periods and 13 desalted periods (Table II).

Figure 1 shows the alterations that occurred in patient E. E. during 61 days of study. The random blood pressure fell during each period of sodium deprivation and rose during each period of added salt. The change in the level of the TEAC floor was in the same direction as that of the random pressure but the magnitude of the change was greater. The response to TEAC was greater during desalted than during salted periods.

Figure 2 shows a 59-day study of patient B. C., whose renal function was good. The level of the random blood pressure was not affected by the changes in the salt balance. The TEAC floor consistently fell in desalted periods and rose in salted periods. The magnitude of the TEAC response was greater in desalted than in salted periods. The serum sodium values showed no consistent changes in this patient.

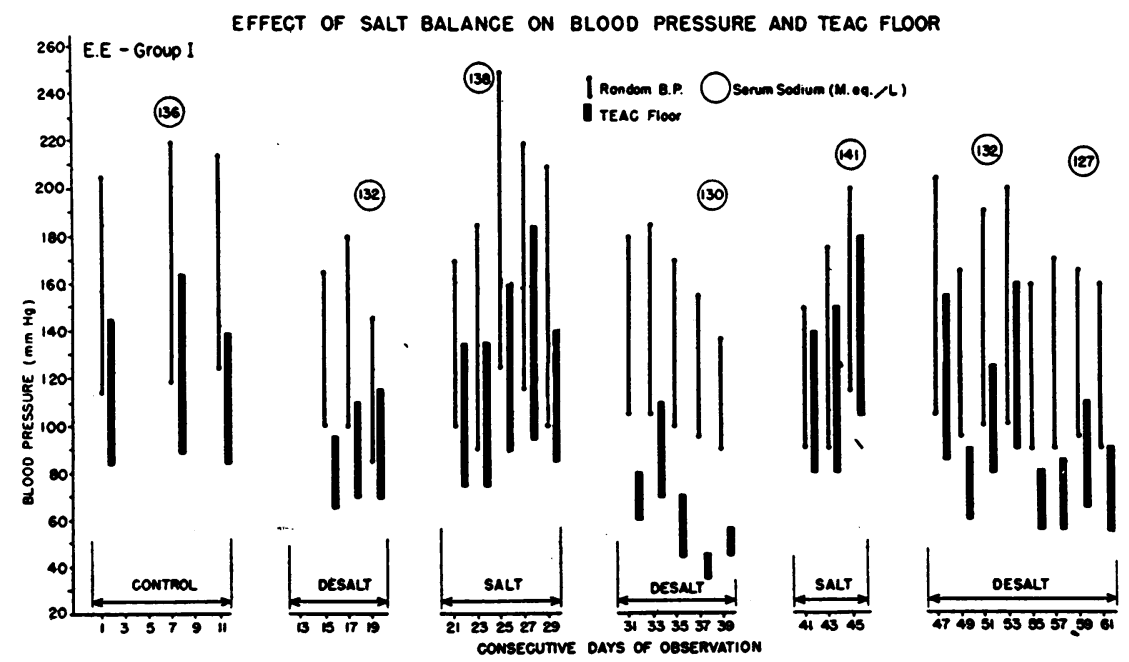

Fig. 1. Illustration of the Random Blood Pressure and TEAC Floor Changes in a Patient of Group I

The thin vertical lines connect systolic and diastolic values for random pressures and the heavy lines for the TEAC floors. The TEAC response is the difference between the random pressure for a given day and the corresponding TEAC floor. The encircled figures indicate the serum sodium values in Milli-equivalents per liter. To avoid crowding only tests done on odd days are recorded. The breaks in the baseline do not represent lapses of time but divide the study into periods. 
EFFECT OF SALT BALANCE ON BLOOD PRESSURE AND TEAC FLOOR
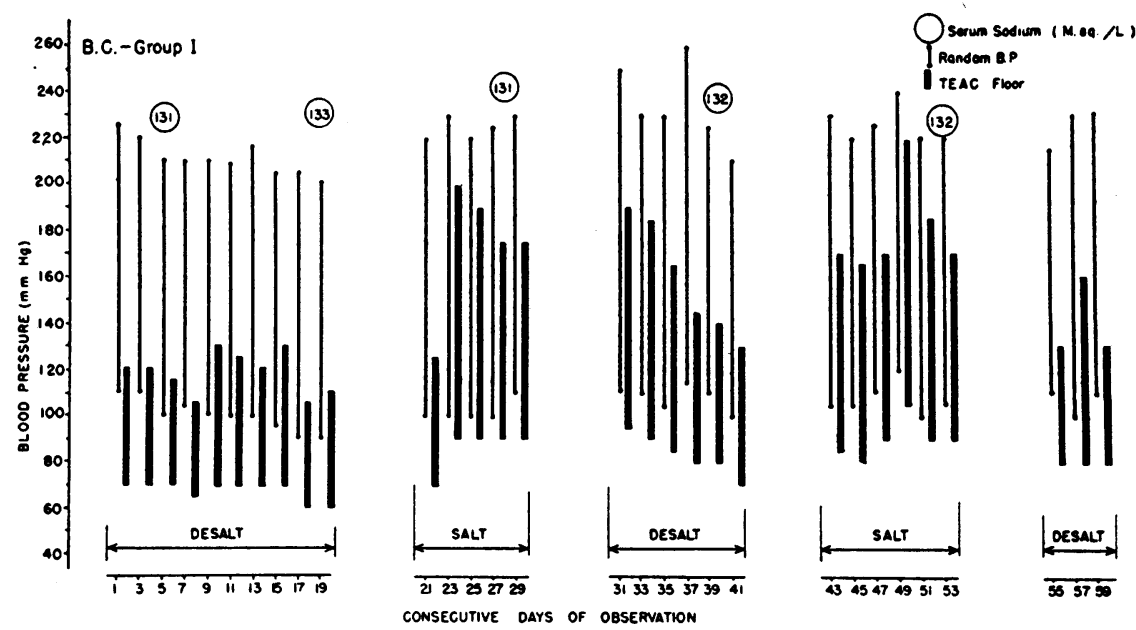

Fig. 2. In this Patient the TEAC Floors Showed Significant Lowering and the TEAC Responses Significant Increases with Sodium Deprivation, but the Random Pressures Were Relatively Constant

The symbols are the same as in Figure 1. The serum sodium changes were neither great nor consistent in this patient.

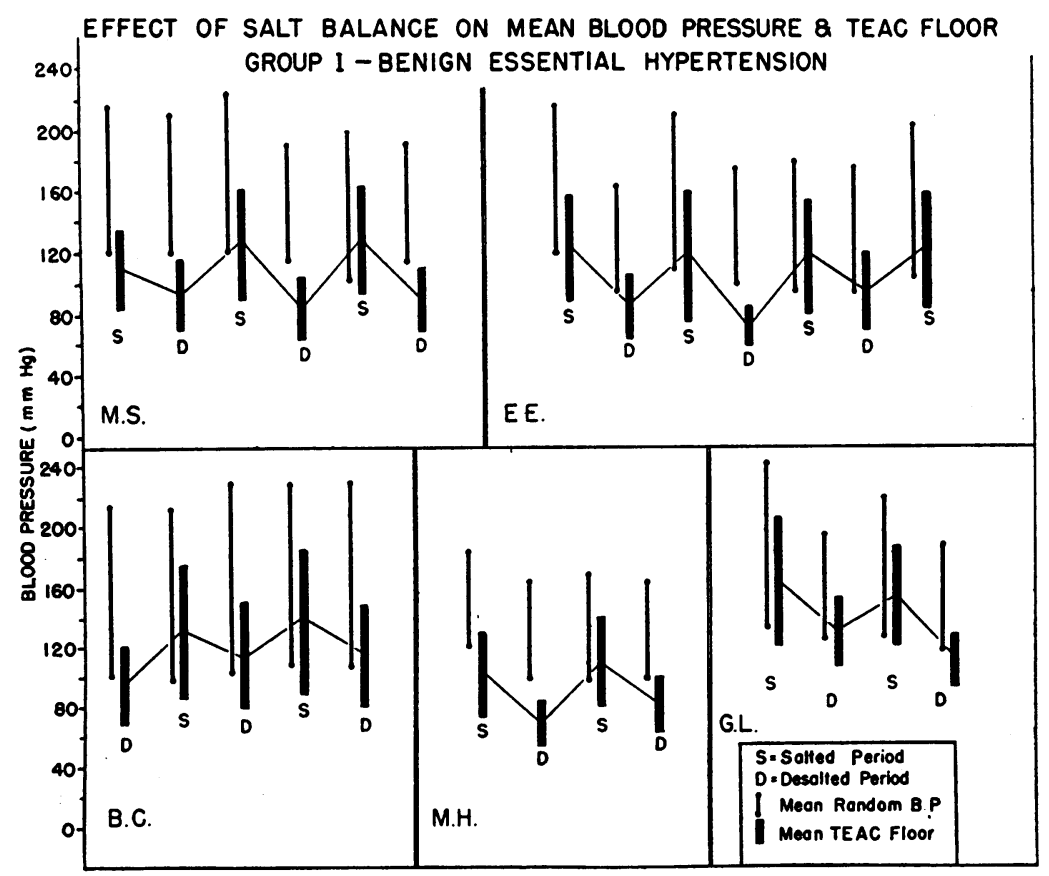

Fig. 3. Mean Random Pressures and teac floors by Pertods for Each Patient of Group I

The random pressures showed but little change, while the TEAC floors were consistently lower in desalted periods. This illustrates the number of times the changes were reproduced in each patient. The horizontal lines connect the midpoints of the TEAC floors for emphasis. 
Figure 3 shows the mean values of the random Group I. All five patients showed a consistent fall blood pressure and TEAC floor in all salted and in the TEAC floor during desalted periods and a desalted periods for each of the five patients of rise during salted periods. This figure also il-

TABLE III

Salted versus desalted state-Group II

Comparison of the means and standard errors of random blood pressure, TEAC floor and TEAC response

\begin{tabular}{|c|c|c|c|c|c|c|c|c|c|}
\hline Patient & State & $\begin{array}{l}\text { Periods } \\
\text { studied }\end{array}$ & $\begin{array}{l}\text { Number } \\
\text { of tests }\end{array}$ & $\underset{\text { pressure }}{\text { Random blood }}$ & P* & $\begin{array}{l}\text { TEAC } \\
\text { floor }\end{array}$ & P* & $\begin{array}{c}\text { TEAC } \\
\text { response }\end{array}$ & P* \\
\hline \multirow{4}{*}{ L. M. } & \multirow{2}{*}{ Salt } & \multirow{2}{*}{2} & \multirow{2}{*}{13} & $\underset{206.5 \pm 3.3}{\operatorname{mm} . H g}$ & \multirow{4}{*}{.05} & $\begin{array}{c}m m . H g \\
184.5 \pm 3.0\end{array}$ & \multirow{4}{*}{$\frac{.02}{.02} \mathrm{Neg} . \dagger$} & $\begin{array}{c}m m . H g \\
22.0 \pm 2.6\end{array}$ & \multirow{4}{*}{$\frac{.9}{.01} \mathrm{Neg} \cdot t$} \\
\hline & & & & $132.6 \pm 2.8$ & & $106.5 \pm 2.4$ & & $26.1 \pm 2.0$ & \\
\hline & \multirow{2}{*}{ Desalt } & \multirow{2}{*}{4} & \multirow{2}{*}{13} & $195.0 \pm 3.9$ & & $173.6 \pm 3.3$ & & $21.4 \pm 2.5$ & \\
\hline & & & & $131.0 \pm 1.6$ & & $115.6 \pm 2.0$ & & $15.4 \pm 2.4$ & \\
\hline \multirow{4}{*}{ I. $\mathrm{H}$. } & \multirow{2}{*}{ Salt } & \multirow{2}{*}{1} & \multirow{2}{*}{3} & $269.7 \pm 10.5$ & \multirow{4}{*}{$\frac{.1}{.6}$} & $224.4 \pm 9.4$ & \multirow{4}{*}{$\frac{.8}{.6}$} & $45.3 \pm 8.2$ & \multirow[b]{2}{*}{1.0} \\
\hline & & & & $177.0 \pm 5.9$ & & $156.7 \pm 4.9$ & & $20.3 \pm 3.9$ & \\
\hline & \multirow{2}{*}{ Desalt } & \multirow{2}{*}{1} & \multirow{2}{*}{7} & $251.7 \pm 3.3$ & & $227.0 \pm 2.3$ & & $24.7 \pm 1.3$ & \multirow[t]{2}{*}{.7} \\
\hline & & & & $\overline{172.0 \pm 5.3}$ & & $153.1 \pm 3.8$ & & $18.9 \pm 1.0$ & \\
\hline \multirow{4}{*}{ F. R. } & \multirow{2}{*}{ Salt } & \multirow{2}{*}{1} & \multirow{2}{*}{4} & $223.5 \pm 4.2$ & \multirow{4}{*}{$\frac{.02}{.1} \mathrm{Neg}$} & $168.0 \pm 9.0$ & \multirow{4}{*}{$\frac{.6}{.05 \mathrm{Neg} .}$} & $55.5 \pm 12.0$ & \multirow{4}{*}{$\frac{.4}{.8}$} \\
\hline & & & & $145.5 \pm 6.3$ & & $108.2 \pm 6.0$ & & $37.3 \pm 5.6$ & \\
\hline & \multirow{2}{*}{ Desalt } & \multirow{2}{*}{1} & 4 & $259.5 \pm 10.6$ & & $177.8 \pm 16.2$ & & $81.7 \pm 20.4$ & \\
\hline & & & 4 & $\overline{165.0 \pm 6.1}$ & & $\overline{130.0 \pm 7.6}$ & & $\overline{35.0 \pm 8.9}$ & \\
\hline & Colt & 1 & 2 & $225.0 \pm 5.0$ & & $198.3 \pm 6.2$ & & $26.7 \pm 7.2$ & \\
\hline $\mathbf{S}$ & Maiti & 1 & 0 & $150.3 \pm 8.5$ & .1 & $144.0 \pm 6.4$ & $.01 \mathrm{Neg}$. & $6.3 \pm 3.4$ & .1 \\
\hline J.5. & Decalt & 1 & 8 & $235.6 \pm 3.1$ & .8 & $223.4 \pm 3.6$ & .3 & $12.2 \pm 4.2$ & .3 \\
\hline & Desall & 1 & 8 & $\overline{153.5 \pm 4.8}$ & & $\overline{152.5 \pm 4.0}$ & & $1.0 \pm 2.7$ & \\
\hline & Salt & 1 & 1 & $175.0 \pm 10.1$ & & $160.0 \pm 11.4$ & & $15.0 \pm 12.6$ & \\
\hline $\mathbf{F} \mathbf{S}$ & & & & $115.0 \pm 8.7$ & .4 & $92.0 \pm 7.6$ & .6 & $23.0 \pm 6.5$ & .9 \\
\hline & Desalt & 1 & 2 & $162.5 \pm 2.5$ & .7 & $150.0 \pm 5.6$ & .5 & $12.5 \pm 7.5$ & .3 \\
\hline & & & & $\overline{110.0 \pm 5.0}$ & & $\overline{101.5 \pm 4.3}$ & & $8.5 \pm 3.5$ & \\
\hline & Salt & 1 & 1 & $240.0 \pm 10.1$ & & $220.0 \pm 11.4$ & & $20.0 \pm 12.6$ & \\
\hline A. B. & & & & $140.0 \pm 8.7$ & .1 & $125.0 \pm 7.8$ & .2 & $\overline{15.0 \pm 6.5}$ & .5 \\
\hline & Desalt & 1 & 3 & $267.7 \pm 8.9$ & .9 & $245.1 \pm 7.6$ & .7 & $31.6 \pm 5.9$ & .8 \\
\hline & & & & $141.7 \pm 9.3$ & & $129.0 \pm 7.1$ & & $\overline{12.7 \pm 3.9}$ & \\
\hline & Salt & 1 & 3 & $246.3 \pm 8.8$ & & $165.0 \pm 17.2$ & & $81.3 \pm 22.6$ & \\
\hline F I & & & & $171.3 \pm 7.2$ & .9 & $118.6 \pm 13.6$ & .7 & $42.7 \pm 17.7$ & .7 \\
\hline & Desalt & 1 & 1 & $245.0 \pm 13.4$ & .7 & $178.0 \pm 15.6$ & .8 & $67.0 \pm 17.0$ & .7 \\
\hline & & & & $\overline{158.0 \pm 17.0}$ & & $\overline{125.0 \pm 11.6}$ & & $\overline{33.0 \pm 9.1}$ & \\
\hline
\end{tabular}

* Probability that the observed change could have been due to chance alone. Values of $P$ of 0.05 or less are usually considered significant.

$t$ Neg. indicates that the change was in the opposite direction from the expected change on the basis of the significant changes in Group I. 
lustrates the number of times these observations were repeated in each patient and the reproducibility of the responses. Table II shows a comparison of the mean random blood pressure, TEAC floor, and TEAC response, in the salted and desalted periods. In all instances a significant shift occurred in both the systolic and diastolic elements of the TEAC floor. Four of the five patients showed a significant change in the random systolic blood pressure, while none showed a significant alteration of the random diastolic pressure. The variations in the TEAC responses were significant except for the systolic component in patient G. L.

Serum sodium determinations were done at representative times throughout the study of four patients of this group. These values are shown in Table IV. In patient E. E. (Figure 1), whose renal function was moderately impaired, the serum sodium concentration was consistently lower in the desalted than in salted periods. The initial sodium level was also moderately low. During the study this patient manifested clinical evidence

TABLE IV

Serum sodium concentrations by periods (Milli-equivalents per liter)

\begin{tabular}{|c|c|c|c|c|c|c|c|}
\hline Name & $\begin{array}{l}\text { Control } \\
\text { period }\end{array} \mid$ & $\begin{array}{c}\text { First } \\
\text { desalt }\end{array}$ & $\begin{array}{l}\text { First } \\
\text { salt }\end{array}$ & $\begin{array}{l}\text { Second } \\
\text { desalt }\end{array}$ & $\begin{array}{c}\text { Second } \\
\text { salt }\end{array}$ & $\begin{array}{l}\text { Third } \\
\text { desalt }\end{array}$ & $\begin{array}{c}\text { Third } \\
\text { salt }\end{array}$ \\
\hline
\end{tabular}

Group I

\begin{tabular}{l|l|l|l|l|l|l|l}
\hline M. S. & 133.7 & $\begin{array}{l}134.6 * \\
134.7^{*}\end{array}$ & 133.4 & 129.4 & 136.5 & 130.7 & \\
\hline E. E. & 135.8 & 132.0 & 137.7 & 127.0 & 141.0 & $\begin{array}{l}132.2 \\
126.8 *\end{array}$ & 136.9 \\
\hline G. L. & & $136.2 *$ & $\begin{array}{l}138.2 \\
141.8\end{array}$ & 129.1 & $\begin{array}{l}135.2 \\
135.8\end{array}$ & & \\
\hline B. C. & & 130.8 & 131.5 & 131.7 & 131.8 & & \\
\hline
\end{tabular}

Group II

\begin{tabular}{l|l|l|l|l|l|l|l}
\hline L. M. & & & & $\begin{array}{l}124.3 \\
126.1^{*} \\
121.3^{*} \\
116.2^{*}\end{array}$ & & & \\
\hline F. R. & 133.1 & 111.4 & 126.5 & $\cdot$ & & & \\
\hline F. S. & 128.8 & 121.3 & & & & & \\
\hline F. I. & 133.0 & 116.6 & 128.5 & & & & \\
\hline
\end{tabular}

* Where more than one value is reported for a given period the first was done near the middle of the period and the others later in the same period. of hypochloremia only once showing weakness, nocturnal delirium and abdominal cramps for three days. This occurred during the second desalted period when her TEAC floor was at its lowest level (Figure 1). At this time the serum sodium level was 130.0 Milli-equivalents per liter, but this was not the lowest level that it reached. The random pressure was about the same as in other desalted periods when the patient showed no symptoms of hypochloremia. In other patients, also, there was no correlation between clinical condition, blood pressure levels and serum sodium concentrations.

All patients lost weight throughout the period of study. A large part of this loss was due to lack of appetite for saltless food. There was in general a loss of 3 to 5 pounds with each period of desalting and a regaining of 2 to 3 pounds with periods of added salt.

It was possible to compute the change in cardiac output produced by TEAC in salted vs. desalted periods in two of the three patients so studied. In Figure 4 the changes in cardiac output and blood pressure observed in patient $M$. S. are charted. The resting output, before the injection of the drug, was not significantly different in the two periods. It can be seen in this patient that a slight increase in cardiac output occurred after TEAC under both conditions. The increase was, if anything, slightly greater in the desalted period. The change in the peripheral resistance produced by TEAC was significantly greater in the desalted state. Similar results were obtained in patient E. E.

Group II. No significant changes occurred in random blood pressure. TEAC floor, or TEAC response in the seven patients of this group. These patients were more seriously ill than those of Group I, all having malignant hypertension, renal failure with uremia, or both. The typical pattern of response in the patients of this group is illustrated in Figure 5. Table III shows a comparison of the average random blood pressure, TEAC floor, and TEAC response in salted and desalted periods for each of the seven patients. Table IV shows the serum sodium concentrations for three patients of this group. The control levels were low in all three patients, ranging from 129 to $133 \mathrm{M}$-eq./L. These changes were greater than those in the patients of Group I, although the desalting regimen 
EFFECT OF TEAC ON BLOOD PRESSURE 8 CARDIAC OUTPUT
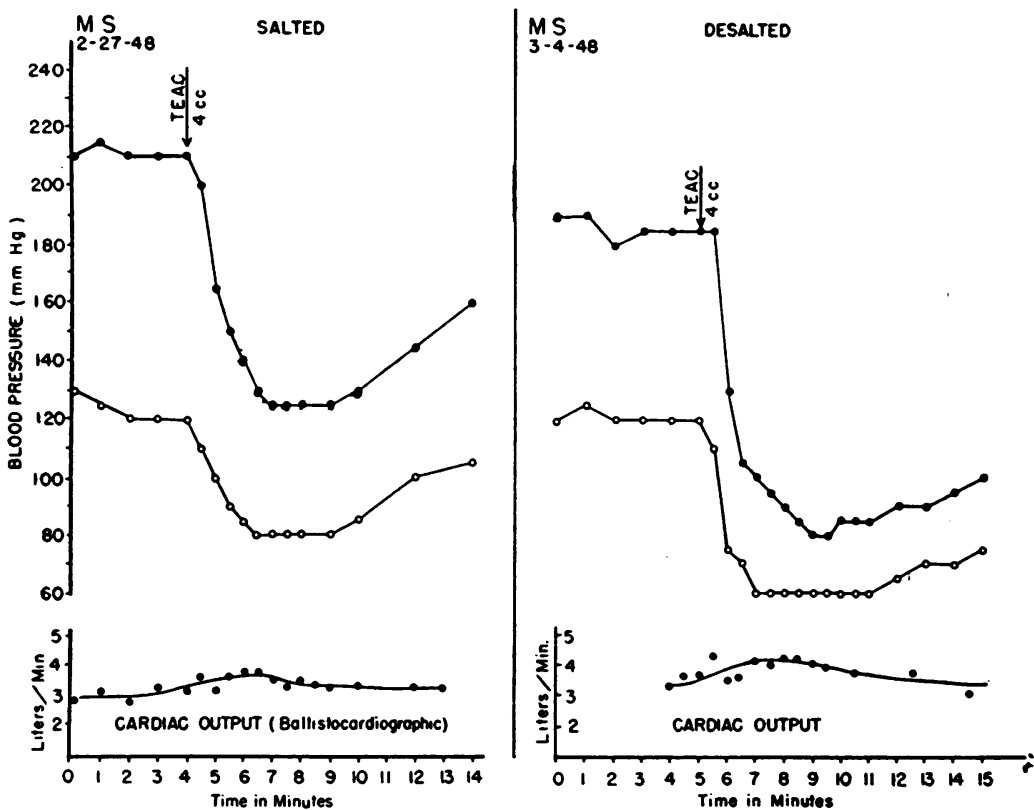

Fig. 4. Simultaneous Cardiac Output (Ballistocardiograph) and Blood Pressure Changes in Response to TEAC in a Salted Period and in a Desalted Period

The resting cardiac output was about the same and the resting blood pressure was similar. In response to TEAC, however, the fall in pressure was significantly greater in the desalted state. The rise in cardiac output was if anything slightly greater when the patient was desalted.

EFFECT OF SALT BALANCE ON BLOOD PRESSURE AND TEAC FLOOR
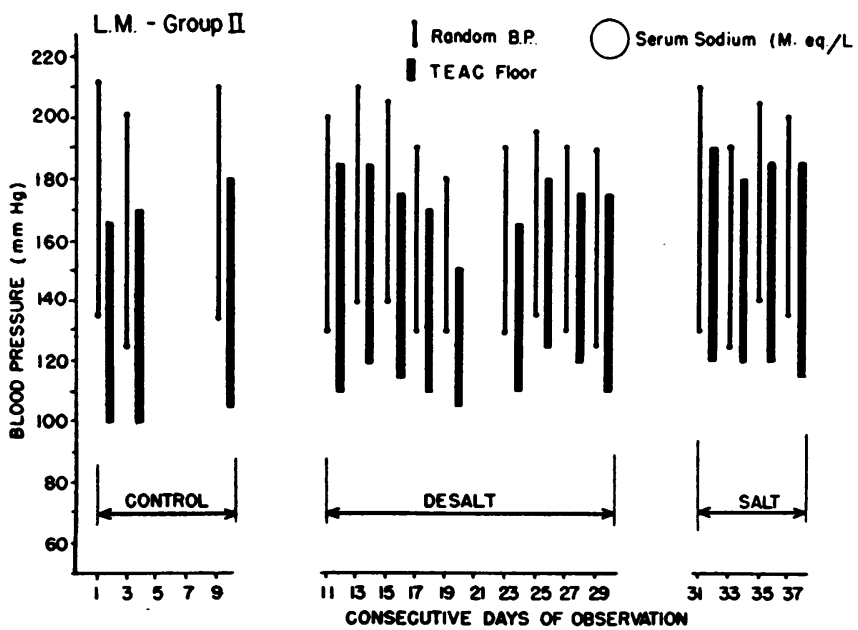

(124)
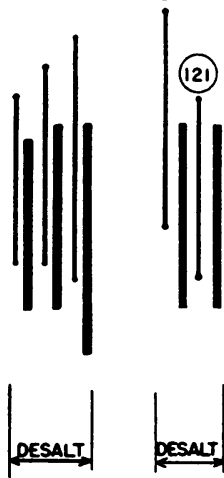

Fig. 5. Record of a Patient of Group II to Show the Lack of Influence of Salt Balance upon the Blood Pressure and Teac floor of Some Hypertensive Patients

The two observations shown at the far right were done at later times, but are similar to the previous results. The original sodium values for this patient are not determined. Later, however, when the serum sodium concentration was at a very low level the blood pressure and TEAC floor were unchanged. 
was less stringent. These data show clearly the lack of effect of alterations of sodium balance on the blood pressure and TEAC floor of the patients of this group.

Figure 6 and Table III show a comparison of blood pressure and TEAC floor during control (salted) and desalted periods in the patients of Group II. Comparison of the mean random blood pressure in salted and desalted periods for any given patient reveals either little change, or a rise in the desalted period. The magnitude of the TEAC response was not increased by desalting in this group.

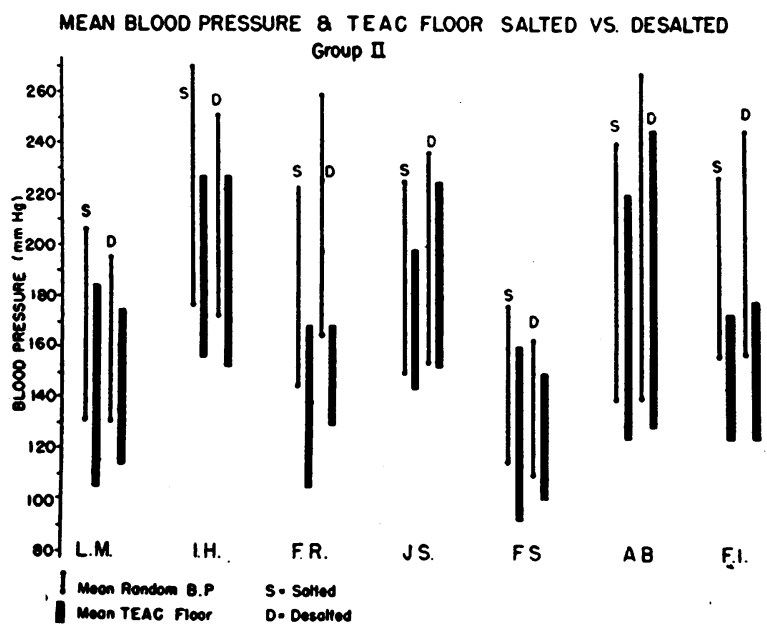

Fig. 6. Comparison of the Means of Random PresSures and TEAC Floors in Control (Salted) ANd Desalted Periods for the Patients of Group II

There is no fall and in some a rise in both values in association with sodium depletion.

Additional observations on two patients, in whom conditions were not controlled adequately to warrant inclusion in the tables, indicate further the lack of correlation between serum sodium levels and blood pressure in some cases of hypertension. The first of these is patient F. R. (Table I), on whom studies are recorded for the control and one desalted period (Figure 6 and Table III), because from that time there were other complicating factors. While on the salt deprivation regimen the condition of the patient deteriorated and her blood pressure rose. The TEAC floor remained about the same. She lost a great deal of weight, became very dehydrated and stuporous. Her serum sodium level fell from 133.1 to $111.4 \mathrm{M}$-eq./
L during this period of two weeks of sodium deprivation. At this time she was partially rehydrated by intravenous administration of normal saline solution with considerable improvement. Following this she was given veratrone and magnesium sulfate for 12 hours in doses sufficient to reduce her blood pressure from $270 / 85$ to $160 / 110 \mathrm{~mm}$. $\mathrm{Hg}$. Concomitantly with this reduction in blood pressure, she lapsed into a coma. Four days later, after her recovery from the coma, the blood pressure and TEAC floor were lower than they had been before the treatment and remained so for four more days. During this time she was clinically greatly improved with the serum sodium level up to 126.5 , and five days later the level was at 130.3 M-eq./L. A reinstitution of the sodium restriction regimen was again followed by a rise in the blood pressure and the TEAC floor, while she lost weight and became more dehydrated and uremic. Autopsy showed malignant nephrosclerosis.

The second patient so studied was F. I., whose serum sodium level fell from 133.0 to $116.0 \mathrm{M}$-eq./ $\mathrm{L}$ in six weeks on sodium deprivation carried out at home. During this time he became somewhat worse clinically, the random pressure rose and TEAC floor remained unchanged. Addition of salt brought the sodium level up to $128.0 \mathrm{M}$-eq./L in three weeks. There was a further rise in the random pressure and no change in TEAC floor during this time. Further rehydration and addition of salt in the hospital was associated with a fall in both the random pressure and TEAC floor. This patient had malignant hypertension, but PSP excretion, concentration capacity, and blood urea nitrogen concentration were all normal. His renal defect seemed to be limited to the inability to conserve electrolytes.

\section{DISCUSSION}

A relationship between the metabolism of sodium chloride and essential hypertension was suggested many years ago by clinical studies $(1,2,7)$. This view has recently been given support experimentally (24-26) and clinically $(3-6,27)$. The possible role of the adrenal cortex in this relationship was suggested by the action of desoxycorticosterone acetate plus an excessive salt intake in producing malignant hypertension in experimental animals (26). In man an increase of blood pressure has been produced by similar means $(28,29)$. 
Perera (6) was able to show the influence of sodium restriction on the early morning blood pressure of patients with uncomplicated essential hypertension. He found that this "resting" pressure was consistently lower when the patient was on a diet containing only $0.2 \mathrm{Gm}$. sodium and returned to control levels when salt was added to the regimen. There was no effect, however, on the pressures taken at random throughout the day. The interpretation given was that the basal humoral component in the blood pressure was diminished by sodium deprivation, but that it was compensated by an increase in neurogenic tone as the patient met life through the day. Comprehensive studies failed to reveal any significant change in serum sodium concentration, cardiac output, plasma volume, etc. His patients all had normal cardiac and renal function. Bryant (3), using a similar regimen, found a significant lowering of the pressures of 100 patients followed in the outpatient clinic. On the other hand, the efficacy of salt restriction in hypertension has been doubted by many authors (8-13). Viersma (13) feels that when adequate control periods are studied-up to two to three months-no significant changes in blood pressure follow sodium restriction.

The validity of inferences with regard to the neurogenic contribution to the blood pressure is based on the work of Acheson and Moe (15) and Acheson and Periera (14) who demonstrated experimentally that the tetraethylammonium ion effectively blocks autonomic impulses at the ganglionic synapse. Lyons et al. (17-19) have studied the effects of this drug in the human and feel that autonomic ganglion blockade is the chief effect of the drug. Reiser and Ferris (20) have shown that the cold pressor response, which is primarily mediated through the autonomic nervous system, is effectively blocked by this drug in man. Ferris et al. (16) feel that the differences in blood pressure response to TEAC, which are noted clinically, are not due to varying degrees of autonomic blockade but can be explained by the variations in the humoral and neurogenic factors operative in different patients with essential hypertension. Similarly, they believe that the relative importance of each of these mechanisms may fluctuate from time to time in the same patient. This would account for the orderly changes in the response to TEAC which they have often observed in re- peated testing of an individual patient and for the different types of responses which characterize hypertension of different etiologies.

If one assumed, on the basis of the above work, that TEAC achieves an effective blockade of autonomic impulses in the ganglia, the following hypothetical picture of the maintenance of peripheral resistance can be set up: (1) The blood pressure at any time (random or casual blood pressure) reflects the total effect of the humoral and neurogenic factors operating, plus whatever intrinsic tone the vascular bed may possess. (2) The fall in pressure produced by TEAC autonomic block (TEAC response) represents the neurogenic component of that random pressure. (3) The pressure following the drug (TEAC floor) reflects the part played by non-neurogenic factors; i.e., all the humoral agents plus the intrinsic tone in a given random blood pressure.

By taking the above formulation as a working hypothesis, our data could be interpreted as follows: In the five patients with benign essential hypertension, whose renal function was fairly well preserved (Group I), the humoral component of the peripheral resistance (as reflected by the TEAC floor) was altered by changes in the salt balance. These patients had the ability to conserve sodium chloride and thus to maintain a relatively isotonic concentration in the blood even against vigorous attempts at sodium depletion. In the seven patients of Group II, the humoral contribution to the elevated blood pressure (TEAC floor) was not altered by shifting the sodium balance. It is of interest to note that all the latter patients either had severe renal damage in the usual sense, or had malignant hypertension. Viersma has shown that patients with malignant hypertension may have an inability to conserve electrolytes as their only manifestation of renal damage and such inability is commonly observed in chronic nephritis.

The change in the TEAC floor of the patients of Group I was much greater than that in the random blood pressures. This suggests that a compensatory rise in the neurogenic contribution to peripheral resistance may occur when the humoral component diminishes. This is consistent with Perera's findings of an alteration only in the early morning pressure with no effect upon the random pressure throughout the day. This compensation is well illustrated by the patient B. C. (Figure 2) in whom 
the random pressure showed no change in the 59 days of study, while the TEAC floor varied significantly with shifts in the sodium balance. In our study the slight changes in random pressures that occurred in some patients may be accounted for by the fact that our desalting regimen was more severe than that used by Perera.

In this interpretation of our data we have assumed that the effect of TEAC is the removal of neurogenic vascular tone by autonomic ganglion blockage. There is a considerable body of evidence to suggest that this assumption is valid, but it has not been conclusively proved in man. The possibility remains that salt deprivation would lower the TEAC floor by altering the ganglionic blocking activity of the drug, instead of altering humoral tone. This possibility does not seem likely in view of present evidence. It appears that the humoral contribution to peripheral resistance may be altered in some patients with benign essential hypertension whose kidneys have the ability to conserve electrolytes for the body. Even in these patients, however, a compensatory rise in the neurogenic contribution to the peripheral resistance may partially or completely offset the decrease of the humoral factor. In other patients whose hypertension is further advanced and whose kidneys have lost the ability to conserve the electrolyte concentration of the body fluids, a further lowering of the body sodium does not affect an apparently large humoral contribution to the peripheral resistance. It is also important to note that even those patients who showed lowering of the random blood pressure and TEAC floor were under closely controlled conditions of a hospital. The results have no bearing on the possible therapeutic effectiveness of salt deprivation in ambulatory hypertensive patients, subject to the usual environmental stresses.

\section{SUMMARY AND CONCLUSIONS}

Random blood pressures and tetraethylammonium chloride "floors" have been studied in 12 hypertensive patients subjected to severe changes in sodium balance.

Five patients showed, on desalting, a significant lowering of the TEAC floor-presumably the nonneurogenic or humoral component of the pressure. In four of these the change in random pressure was less striking, apparently because of a compensatory rise in the neurogenic contribution, as indicated by an increase in the TEAC response in the desalted periods. Serum sodium concentrations were slightly below normal in the control periods, but showed no consistent changes during subsequent salted and desalted periods.

Seven patients showed no change in either random or TEAC floor pressures. The data showed that in these patients a fall of 15 to $20 \mathrm{M}$.-eq. per liter in the serum sodium concentration was associated with no fall in the random pressure or the TEAC floor. This is in contrast to the patients of Group $I$ in whom a minor change in serum sodium concentration was associated with a striking fall in what seems to be the humoral component of the blood pressure.

In general, the results suggest:

(1) That in some patients with essential hypertension and only moderately impaired renal function, the important change during sodium deprivation may be a lessening of the humoral contribution to the maintenance of an increased peripheral resistance.

(2) That in other patients with malignant hypertension, renal failure, or both, an apparently large humoral component in peripheral resistance may be uninfluenced by an even greater degree of sodium depletion.

\section{ACKNOWLEDGMENT}

The authors are indebted to Dr. John Braunstein for the ballistocardiographic studies. Miss Lois Denny, of the Dietetics Department, was of great value in controlling the sodium content of the diets and in maintaining the cooperation of the patients. The serum sodium studies were done by Miss Nancy Hobson of the Children's Hospital Research Foundation.

\section{BIBLIOGRAPHY}

1. Allen, F. M., and Sherrill, J. W., Treatment of arterial hypertension. J. Metab. Research, 1922, 2, 429.

2. Ambard, L., and Beauyard, E., La retention chlorurée sèche. Semaine méd., 1905, 25, 133.

3. Bryant, J. M., and Blecha, E., Low sodium-forced fluid management of hypertensive vascular disease and hypertensive heart disease. Proc. Soc. Exper. Biol. \& Med., 1947, 65, 227.

4. Grollman, A., Harrison, T. R., Mason, M. F., Baxter, J., Crampton, J., and Reichman, F., Sodium restriction in diet for hypertension. J. A. M. A., 1945, 129, 533. 
5. Kempner, W., Compensation of renal metabolic dysfunction. Treatment of kidney disease and hypertensive disease with rice diet. North Carolina M. J., 1944, 5, 125 and $273 ; 1945,6,61$ and 117.

6. Perera, G. A., and Blood, D. W., The relationship of sodium chloride to hypertension. J. Clin. Invest., 1947, 26, 1109.

7. Volhard, F., Die Behandlung der Sklerosen, in: von Bergman, G., and Staehelin, R., Handbuch der inneren Medizin. Julius Springer, Berlin, 1931, Vol. 6, Ed. 2.

8. Ayman, D., Arterial hypertension, in: Oxford Medicine, Christian, H. A. Oxford Press, New York, 1947, Vol. 2, p. 508.

9. Goldring, W., and Chasis, H., Hypertension and Hypertensive Disease. The Commonwealth Fund, New York, 1944.

10. McLester, J. S., The influence of rigid salt restriction in the diet of chronic nephritis. Am. J. M. Sc., 1922, 163, 794.

11. Mosenthal, $H$. O., The treatment of high blood pressure. M. Clinics N. America, 1922, 5, 1139.

12. Schroeder, H. A., Low salt diets and arterial hypertension. Am. J. Med., 1948, 4, 578.

13. Viersma, H. J., De Behandlung Van Hypertensie Met Zoutloos Dieet En Met Uitdrijving Van Keukenzout: Een Klinische en Haemodynamische Studie. N.V. Noord-Hollandsche Uitgevers Maatschappij, Amsterdam, 1945.

14. Acheson, G. H., and Periera, S. A., The blocking effect of tetraethylammonium ion on the superior cervical ganglion of the cat. J. Pharmacol. \& Exper. Therap., 1946, 87, 273.

15. Acheson, G. H., and Moe, G. K., The action of the tetraethylammonium ion on the mammalian circulation. J. Pharmacol. \& Exper. Therap., 1946, 87, 220.

16. Ferris, E. B., Jr., Reiser, M. F., Stead, W. W., and Brust, A. A., Clinical and physiological observations of interrelated mechanisms in arterial hypertension. Tr. A'. of Am. Physicians (In press).

17. Lyons, R. H., Campbell, K. N., Moe, G. K., Neligh, R. B., Hoobler, S. W., Berry, R. L., and Rennick, B. R., The effects of blockade of autonomic ganglia in man with tetraethylammonium. Am. J. M. Sc., $1947,213,315$.
18. Lyons, R. H., Hoobler, S. W., Neligh, R. B., Moe, G. K., and Peet, M. M., Experiences with tetraethylammonium chloride in hypertension. J. A: M. A., 1948, 136, 608.

19. Lyons, R. H., Moe, G. K., Neligh, R. B., Hoobler, S. W., Campbell, K. N., Berry, R. L., and Rennick, B. R., The effects of blockade of the autonomic ganglia in man; preliminary observations on use of tetraethylammonium chloride. Univ. Hosp. Bull., Ann Arbor, 1946, 12, 33.

20. Reiser, M. F., and Ferris, E. B., Jr., The nature of the cold pressor test and its significance in relation to neurogenic and humoral mechanisms in hypertension. J. Clin. Invest., 1948, 27, 156.

21. Adler, F. H., Gifford's Textbook of Ophthalmology. W. B. Saunders Co., Philadelphia, 1947, Ed. 4.

22. Levinson, J. E., Reiser, M. F., and Ferris, E. B., Jr., Variations in the blood pressure response to repeated administration of tetraethylammonium chloride. J. Clin. Invest., 1948, 27, 154.

23. Butler, A. M., and Tuthill, E., An application of the uranyl zinc acetate method for determination of sodium in biological material. J. Biol. Chem., 1931, 93, 171.

24. Grollman, A., and Harrison, T. R., Effect of rigid sodium restriction on blood pressure survival of hypertensive rats. Proc. Soc. Exper. Biol. \& Med., 1945, 60, 52.

25. Knowlton, A. I., Loeb, E. N., Stoerck, H., and Seegal, B. C., Desoxycorticosterone acetate: the potentiation of its activity by sodium chloride. J. Exper. Med., 1947, 85, 187.

26. Selye, H., Hall, C. E., and Rowley, E. M., Malignant hypertension produced by treatment with desoxycorticosterone acetate and sodium chloride. Canad. M. A. J., 1943, 49, 88.

27. Perera, G. A., and Blood, D., Disturbances in salt and water metabolism in hypertension. Am. J. Med., 1946, 1, 602.

28. Perera, G. A., and Blood, D., Pressor activity of desoxycorticosterone acetate in normotensive and hypertensive subjects. Ann. Int. Med., 1947, 27, 401.

29. Perera, G. A., The relationship of the adrenal cortex to hypertension; observations on the effect of hypoadrenalism on a patient with hypertensive vascular disease. J. A. M. A., 1945, 129, 537. 